\section{Family structure and use of prenatal care}

\section{Estrutura familiar e uso de cuidados pré-natais}

\author{
Estructura familiar y utilización de servicios de \\ cuidados prenatales
}

\author{
${ }^{1}$ Instituto de Saúde Pública, \\ Universidade do Porto, Porto, \\ Portugal. \\ 2 Centro de Saúde \\ Carvalhosa, Porto, Portugal. \\ Correspondence \\ E. Alves \\ Instituto de Saúde Pública, \\ Universidade do Porto. \\ Rua das Taipas 135, Porto \\ 4050-600, Portugal. \\ ealves@med.up.pt
}

\begin{abstract}
This cross-sectional study intended to assess the use of prenatal care according to the family structure in a population with free universal access to prenatal care. In 2005-2006, the Portuguese birth cohort was assembled by the recruitment of puerperae at public maternity wards in Porto, Portugal. In the current analysis, 7,211 were included. Data on socio-demographic characteristics, obstetric history, and prenatal care were self-reported. Single mothers were considered as those whose household composition did not include a partner at delivery. Approximately 6\% of the puerperae were single mothers. These women were more likely to have an unplanned pregnancy $(\mathrm{OR}=$ 6.30; 95\%CI: 4.94-8.04), an inadequate prenatal care $(O R=2.30 ; 95 \% C I: 1.32-4.02)$, and to miss the ultrasound and the intake of folic acid supplements during the first trimester of pregnancy $(O R=1.71 ; 95 \% C I: 1.30-2.27$; and $O R=1.67 ; 95 \% C I: 1.32-2.13$, respectively). The adequacy and use of prenatal care was less frequent in single mothers. Educational interventions should reinforce the use and early initiation of prenatal care.
\end{abstract}

Single-Parent Family; Prenatal Care; Pregnancy
Elisabete Alves 1

Susana Silva 1

Simone Martins 2

Henrique Barros 1

\section{Resumo}

Este estudo transversal pretende avaliar a utilização dos cuidados pré-natais segundo a estrutura familiar, numa população com acesso universal e gratuito a estes cuidados. Em 2005-2006, puérperas foram recrutadas em maternidades públicas do Porto, Portugal, na coorte de nascimento portuguesa. Nesta análise, foram incluídas 7.211 mulheres. Dados sobre as características sociodemográficas, antecedentes obstétricos e cuidados pré-natais foram reportados. Definiram-se como mães monoparentais todas aquelas que não viviam em casal na altura do parto. Cerca de 6\% eram mães monoparentais. Essas mulheres eram mais propensas a ter uma gravidez não planejada $(O R=6,30 ;$ IC95\%: 4,94-8,04), cuidados pré-natais inadequados (OR = 2,30; IC95\%: 1,32-4,02) e a não realizar uma ecografia e iniciar a ingestão de ácido fólico durante o primeiro trimestre da gravidez $(O R=1,71$; IC95\%: 1,30-2,27; e OR = 1,67; IC95\%: 1,32-2,13, respectivamente). A adequação e utilização de cuidados pré-natais foram menos frequentes em mães monoparentais. As intervenções educativas devem reforçar o uso e início precoce dos cuidados pré-natais.

Família de Pais Solteiros; Cuidado Pré-Natal; Gravidez 


\section{Introduction}

Family structure, as measured by marital status, family social support or household size and composition, is regarded as a social health determinant 1 . Overall, married people, as well as their children, tend to be described as enjoying better health than those who are not married 2,3. Evidence has shown that members of two-parent families presented lower prevalence of depression, anxiety and chronic diseases, than members of single-parent families $4,5,6$, as well as a lower risk of all-cause mortality 7 . Better health status in two-parent families have been explained through higher levels of social support and financial security ${ }^{4}$, reduction of health-related risky behaviors and higher prevalence of health-promoting behaviors 8 .

Such benefits influence health conditions and psychological wellbeing over the life course 9,10, conferring perinatal advantage 11 . Being married increases the probability of planning pregnancy, timely and adequate antenatal care, improves emotional well-being during and after pregnancy, and reduces high-risk behaviors like drinking and smoking during pregnancy 12,13. Also, it is well-documented that unmarried mothers are at higher risk of adverse perinatal outcomes, such as preterm birth, low birth weight, smallfor-gestational age, and fetal and neonatal mortality $12,14,15,16$.

In contrast to research on family structure and perinatal care, which evaluate health conditions at and after birth, very few studies focused on prenatal care and single motherhood. While a recent systematic review identified non-marital status as an individual determinant of inadequate and/or late use of prenatal care in highincome countries, it concluded that evidence is scarce and comprehensive data is still lacking ${ }^{11}$. Given the role of prenatal care in reducing adverse outcomes of pregnancy for mothers and their children, tracing the psychosocial and health implications of single motherhood in such a stage of their lives may be helpful in the identification of opportunities for primary prevention.

Therefore, the aim of this study was to assess the use of prenatal care according to the family structure (single motherhood vs. two-parent family) in a population with free universal access to prenatal care.

\section{Methods}

This cross-sectional study is based on the Portuguese birth cohort, Geração XXI, assembled between April 2005 and August 2006 at all five public maternity units covering the metropolitan area of Porto, Portugal 17. The maternity units are level III units, with differentiated perinatal support, and all but one were included in general hospitals, with the full range of medical and surgical specialist services. Approximately $75 \%$ of women who delivered live born infants ( $>24$ weeks) were invited to participate in the cohort ( $n=9,294)$, and $91.4 \%$ accepted. Information on pregnancy exposures was collected retrospectively ${ }^{18}$. The present study is based on 8,182 mothers, after excluding 313 who had been recruited, for other specific purposes, in the first trimester of pregnancy. As late prenatal care is one of the indicators under analysis, the inclusion of this group of women would distort the results, overestimating the proportion of women who attended the first appointment during the initial 12 weeks of gestation.

Self-reported data on demographic and socioeconomic characteristics, obstetric history, and prenatal care were collected within 72 hours after delivery, during the hospital stay, in a face-to-face interview conducted by trained interviewers using structured questionnaires. According to the definition of the National Institute of Statistics, single mothers were considered as those whose household composition at delivery did not include a partner, and who lived alone or with other relatives (i.e., nuclear and extended single parent families). Pregnancy planning and place of prenatal care as well as data regarding the ultrasound and the intake of folic acid supplements in the first trimester were self-reported by the mother at birth. Adequacy of prenatal care was classified using the Adequacy of Prenatal Care Utilization Index (APNCU) 19, based on the combination of the week of initiation of prenatal care, the observed and expected number of prenatal visits and the gestational age at birth. According to the APNCU index, having less than $50 \%$ of the recommended number of prenatal visits for a given gestational age (4 prenatal visits if 24-25 weeks of gestation, 5 prenatal visits if 26-29 weeks of gestation, 6 prenatal visits if 30-31 weeks of gestation, 7 prenatal visits if 3233 weeks of gestation, 8 prenatal visits if 34-35 weeks of gestation, and 9 or more prenatal visits if $\geq 36$ weeks of gestation) or initiation of prenatal care after the fourth month of pregnancy was defined as inadequate care. All other categories of prenatal care require initiation of care by the fourth month of pregnancy, being divided in intermediate, adequate and adequate plus, according to the proportion of recommended prenatal visits attended (50-79\%, 80-109\% and more than $109 \%$, respectively). 
After exclusion of the participants who presented at least one missing value on age, education, parity, pregnancy planning, adequacy of prenatal care, performing an ultrasound in the first trimester, folic acid supplements, place of prenatal care and family structure, 7,192 women were included in our analysis. There were no significant differences between participants with complete and missing data regarding age [mean (standard deviation - SD): 29.0 (5.5) vs. 29.1 (5.9) years, $\mathrm{p}=0.549$ ], while women with no missing data on key variables were more frequently primiparae $(57.4 \%$ vs. $51.3 \%, \mathrm{p}=0.001)$, had a higher educational level [median (interquartile range-IQR): 10 (7-12) vs. 9 (6-12) years, $\mathrm{p}<0.001$ ] and were less likely to be single mothers $(5.9 \%$ vs. $7.9 \%, \mathrm{p}=0.022$ ).

Statistical analysis was performed using Stata 9.0 (Stata Corp., College Station, USA). Sample characteristics are presented as counts and proportions and were compared using the chisquare test. The prevalence of the outcome is presented with 95\% confidence intervals (95\%CI). Crude and adjusted odds ratios (OR) and 95\%CI were estimated by unconditional binary logistic regression models to assess the association between the mother's family structure and use of prenatal care. Indicators of prenatal care were selected based on a review of the literature, and included pregnancy planning, the adequacy of prenatal care, the performing of an ultrasound in the first trimester of pregnancy, the intake of folic acid supplements during the first 12 weeks of gestation and the place of prenatal care. Due to collinearity between the variables, performing an ultrasound and take folic acid supplements in the first trimester were not simultaneously adjusted for one other. Similarly, pregnancy planning and the adequacy and place of prenatal care were not adjusted for performing an ultrasound and the intake of folic acid. The final model also included socio-demographic characteristics and obstetric history, which are known to be possible confounders.

All the phases of the study complied with the Ethical Principles for Medical Research Involving Human Subjects expressed in the Declaration of Helsinki. The study protocol was approved by the University of Porto Medical School/São João Hospital Centre Ethics Committee and by the Portuguese Authority of Data Protection. Written informed consent was obtained from all participants.

\section{Results}

The characteristics of the study participants are summarized in Table 1. In this sample of women, 5.9\% (95\%CI: 5.4-6.5) were single mothers. They were significantly younger, less educated and less likely to be employed than two-parent families. These women were also more frequently primiparae and relied solely on public prenatal care more often. The inadequacy of prenatal care and unplanned pregnancies were higher among this group of women. Performing an ultrasound in the first trimester was significantly less frequent in single-parent families, as well as the intake of folic acid supplements during the same period of time.

After adjustment for potential confounders, single motherhood was significantly associated with an inadequate and/or late use of prenatal care (Table 2). Single-mothers were more likely to have an unplanned pregnancy $(\mathrm{OR}=6.34$; 95\%CI: 4.97-8.10) and inadequate prenatal care $(\mathrm{OR}=2.24$; 95\%CI: 1.28-3.91). Exclusively private prenatal care, as well as simultaneously public and private, were significantly less frequent among single mothers (OR $=0.56$; 95\%CI: 0.39 0.08 and $\mathrm{OR}=0.39$; $95 \% \mathrm{CI}: 0.24-0.65$, respectively). Furthermore, these women were $65 \%$ and $63 \%$ more likely to have missed the first trimester ultrasound and the intake of acid folic supplements during the first 12 weeks of gestation, respectively. When including missing values as category, the associations described between use of prenatal care and single motherhood remained similar (data not shown).

\section{Discussion}

Consistent with previous studies 11, our findings showed that single motherhood is associated with late initiation or inadequate use of prenatal care. These women were more likely to have an unplanned pregnancy, inadequate prenatal care, and to miss the ultrasound and the intake of acid folic supplements during the first 12 weeks of gestation. They were also more frequently accompanied exclusively at public prenatal care providers. These results may be explained by limited social support and lack of financial resources 4 , adverse social conditions that constrain the capacity of mothers to find and use prenatal care services 20 , social stigma ${ }^{9}$ and stress exposure 10 .

The socio-demographic profile of single mothers of the Portuguese birth cohort may also explain the increased odds of late initiation or inadequate use of prenatal care. Similar to other high-income countries, single motherhood 
Characteristics of the participants and use of prenatal care, according to family structure.

\begin{tabular}{|c|c|c|c|}
\hline & $\begin{array}{l}\text { Single motherhood }(n=425) \\
n(\%)\end{array}$ & $\begin{array}{l}\text { Two-parent family }(n=6,767) \\
n(\%)\end{array}$ & $\mathrm{p}$-value \\
\hline \multicolumn{4}{|l|}{ Age (years) } \\
\hline$<25$ & $264(62.1)$ & $1,313(19.4)$ & \\
\hline $25-29$ & $81(19.1)$ & $2,084(30.8)$ & \\
\hline $30-34$ & $52(12.2)$ & $2,244(33.2)$ & \\
\hline$\geq 35$ & $28(6.6)$ & $1,126(16.6)$ & $<0.001$ \\
\hline \multicolumn{4}{|l|}{ Education (years) } \\
\hline$<5$ & $34(8.0)$ & $480(7.1)$ & \\
\hline $5-9$ & $247(58.1)$ & $2,698(39.9)$ & \\
\hline $10-12$ & $99(23.3)$ & $1,861(27.5)$ & \\
\hline$\geq 13$ & $45(10.6)$ & $1,728(25.5)$ & $<0.001$ \\
\hline \multicolumn{4}{|l|}{ Employment status } \\
\hline Employed & $167(39.5)$ & $5,018(74.1)$ & \\
\hline Unemployed & $157(37.1)$ & $1,261(18.6)$ & \\
\hline Housewife & $26(6.2)$ & $380(5.6)$ & \\
\hline Other (student/retired) & $73(17.3)$ & $116(1.7)$ & $<0.001$ \\
\hline \multicolumn{4}{|l|}{ Parity } \\
\hline 0 & $349(82.1)$ & $3,777(55.8)$ & \\
\hline$\geq 1$ & $76(17.9)$ & $2,990(44.2)$ & $<0.001$ \\
\hline Planned pregnancy (yes) & $103(24.2)$ & $4,777(70.6)$ & $<0.001$ \\
\hline \multicolumn{4}{|l|}{ Adequacy of prenatal care * } \\
\hline Adequate plus & $26(6.1)$ & $612(9.0)$ & \\
\hline Adequate & $173(40.7)$ & $2,993(44.2)$ & \\
\hline Intermediate & $185(43.5)$ & $2,896(42.8)$ & \\
\hline Inadequate & $41(9.7)$ & $266(3.9)$ & $<0.001$ \\
\hline $\begin{array}{l}\text { Ultrasound in the } 1 \text { st trimester } \\
\text { (yes) }\end{array}$ & $314(73.9)$ & $6,163(91.1)$ & $<0.001$ \\
\hline $\begin{array}{l}\text { Folic acid supplementation } \leq 12 \\
\text { weeks (yes) }\end{array}$ & $268(63.1)$ & $5,675(83.9)$ & $<0.001$ \\
\hline \multicolumn{4}{|l|}{ Place of prenatal care } \\
\hline Public & $363(85.4)$ & $4,053(60.0)$ & \\
\hline Private & $43(10.1)$ & $1,910(28.2)$ & \\
\hline Public and private & $19(4.5)$ & $804(11.8)$ & $<0.001$ \\
\hline
\end{tabular}

*According to the Adequacy of Prenatal Care Utilization Index (APNCU) 19.

Note: in employment status variable the total does not add to 7,192 due to missing data.

is associated with younger age and lower education 11,21. Evidence has suggested that social and environmental factors, namely socio-economic position, appear to explain the association of young maternal age with adverse perinatal outcomes 22 .

In the present sample, approximately $6 \%$ of the women were single mothers. In 2005 and 2006, the period corresponding to the assembling of Geração XXI, the prevalence of live births outside marriage and without cohabiting parents in Portugal was $6 \%$ and $6.3 \%$, respectively, slightly higher than that observed in the north of Portugal (5.5\% and $6 \%$, respectively) 23 . The European Program of Occupational Risks and Pregnancy Outcome (EUROPOP) reported that the prevalence of single women giving birth, between 1994 and 1997, ranged from 0\% in Greece to $17 \%$ in Ireland 15 . In Canada the prevalence of single mothers at birth in 2004 was $8 \% 24$. In Portugal, the percentage of live births outside marriage and without cohabiting parents increased more than $80 \%$, from $6 \%$ to $10.9 \%$, between 2001 and 201123 . The growing trend of single moth- 
Crude and adjusted odds ratios for the association between use of prenatal care and single motherhood.

\begin{tabular}{lcc}
\hline & Crude OR (95\%Cl) & Adjusted OR * (95\%Cl) \\
\hline $\begin{array}{l}\text { Planned pregnancy } \\
\text { Yes }\end{array}$ & 1.00 & 1.00 \\
No & $7.50(5.97-9.43)$ & $6.34(4.97-8.10)$ \\
Adequacy of prenatal care ** & 1.00 & 1.00 \\
$\quad$ Adequate plus & $1.36(0.89-2.07)$ & $1.39(0.89-2.18)$ \\
Adequate & $1.50(0.99-2.29)$ & $1.40(0.90-2.18)$ \\
Intermediate & $3.63(2.17-6.05)$ & $2.24(1.28-3.91)$ \\
Inadequate & 1.00 & 1.00 \\
Ultrasound in the 1st trimester & $3.61(2.86-4.55)$ & $1.65(1.24-2.18)$ \\
Yes & 1.00 & 1.00 \\
No & $3.04(2.47-3.75)$ & $1.63(1.28-2.07)$ \\
Folic acid supplementation $\leq 12$ weeks & & 1.00 \\
Yes & 1.00 & $0.56(0.39-0.80)$ \\
No & $0.25(0.18-0.35)$ & $0.39(0.24-0.65)$ \\
Place of prenatal care & $0.26(0.17-0.42)$ & \\
Public & & \\
Private & & \\
Public and private & & \\
\hline
\end{tabular}

95\% Cl: 95\% confidence interval; OR: odds ratio.

* Performing an ultrasound in the first trimester and to take folic acid supplements in the first trimester were adjusted for age, educational level, parity, pregnancy planning, adequacy of prenatal care and place of prenatal care. Pregnancy planning, adequacy of prenatal care and place of prenatal care were adjusted each other, age, educational level and parity; ** According to the Adequacy of Prenatal Care Utilization Index (APNCU) ${ }^{19}$.

erhood at birth in Portugal was also observed during the 1990s, a period characterized by increasing rates of relationships not formalized by marriage, as well as a higher incidence of sexual precocity, sometimes associated with unplanned adolescent pregnancies 25 .

Over the last two to three decades, perinatal health in Portugal has experienced a huge overall improvement, ensuring all citizens free access to primary care centers and public hospitals, but the use of preconceptional care remains low 26 . It is important to invest in pregnancy planning and to extend and enlarge knowledge on family and social relationships and on medical care among single mothers at birth, regarding the support and care provided during their pregnancies, including a comparative analysis between extended and nuclear single-parent families. At the same time, the strengthening of technical support units to pregnant women and newborns, with special attention to the promotion of preconceptional care and quality control of ultrasound scans in pregnancy is crucial.

This is the first study to assess the use of prenatal care according to family structure in a country with universal and free access to prenatal care. A potential for recall bias did not exist, as consistent information was obtained by self-report and medical record review with regard to pregnancy and well-known risk factors 27 . However, some limitations should be noted. Despite the previously described positive effect of paternal involvement on the adoption of healthier behaviors during pregnancy, information regarding this variable was not assessed in the present study. Additionally, women delivering in private care facilities were not present in this study. While there is no evidence of the characteristics of women actively choosing to have a child without the involvement of a partner in Portugal, it is possible that these women more frequently use private care settings, which might impact on the estimate of prevalence described in our study and on the use of prenatal care. These women have been typically described as a distinct subgroup of single mothers, aged over 30, highly educated, with well-paid jobs and who are financially secure, whose decision to have a child alone was based on their age, social class, level of responsibility and emotional 
maturity 28 . However, a significant underestimation of the proportion of single motherhoods is unlikely due to the similar prevalence obtained in our study and that provided by the national data for the north of Portugal, at that time 23.

In conclusion, the adequacy and utilization of prenatal care was less frequent in single mothers. Educational interventions should advocate for the use and early initiation of prenatal care as an important means of reducing disparities in the surveillance of pregnant women. For the global improvement of prenatal care it is important to promote family planning among all women, whether they are living with a partner or not, focusing on the youngest and less educated as a target for health promotion. Also, there is a need for a better and in-depth understanding of the barriers single women face during pregnancy that lead to the inadequate use of prenatal services. Women need to be outreached in early pregnancy, which calls for the development of research on perinatal health of single mothers.

\section{Resumen}

Este estudio transversal pretende evaluar la utilización de la atención prenatal, de acuerdo con la estructura familiar, en una población con acceso universal y gratuito a la atención prenatal. En 2005-2006, se seleccionaron puérperas en maternidades públicas de Porto, Portugal en una cohorte de nacimientos portuguesa. En el análisis, se incluyeron 7.211. Se informaron sobre datos como: características sociodemográficas, historia obstétrica y atención prenatal. Las madres monoparentales son las que no tenían un compañero en el momento del parto. Aproximadamente un $6 \%$ eran madres monoparentales. Estas tenían más probabilidades de tener un embarazo no planificado $(O R=$ 6,30; IC95\%: 4,94-8,04), atención prenatal inadecuada $(O R=2,30$; IC95\%: 1,32-4,02), y perder la ecografía y la ingesta de ácido fólico durante el primer trimestre del embarazo $(O R=1,71$; IC95\% 1,30-2,27; y OR = 1,67; IC95\%: 1,32-2,13; respectivamente). La adecuación y el uso de la atención prenatal fueron menos frecuentes en las madres monoparentales. Las intervenciones educativas deben promover el uso y el inicio temprano de la atención prenatal.

Familia de Padres Solteros; Atención Prenatal; Embarazo

\section{Contributors}

E. Alves collaborated on the acquisition, analysis and interpretation of the data and wrote the article. S. Silva and S. Martins contributed on data interpretation and reviewed the article critically. $\mathrm{H}$. Barros designed the study, analyzed and interpreted the data and reviewed the article critically.

\section{Acknowledgments}

The authors gratefully acknowledge the families enrolled in Geração XXI for their kindness, all members of the research team for their enthusiasm and perseverance and the participating hospitals and their staff for their help and support. 


\section{References}

1. Lee K, Koivusalo M, Ollila E, Labonté K, Schrecker T, Schuftan C, et al. Globalization, global governance and the social determinants of health: a review of the linkages and agenda for action. Ottawa: Institute of Population Health; 2007.

2. Huijts T, Kraaykamp G. Marital status, nation marital status composition, and self-assessed health: a multilevel test of four hypotheses in 29 European countries. European Societies 2011; 13:279-305.

3. Bramlett MD, Blumberg SJ. Family structure and children's physical and mental health. Health Aff (Millwood) 2007; 26:549-58.

4. Crosier T, Butterworth P, Rodgers B. Mental health problems among single and partnered mothers. The role of financial hardship and social support. Soc Psychiatry Psychiatr Epidemiol 2007; 42:6-13.

5. Holt-Lunstad J, Birmingham W, Jones BQ. Is there something unique about marriage? The relative impact of marital status, relationship quality, and network social support on ambulatory blood pressure and mental health. Ann Behav Med 2008; 35:239-44.

6. Turagabeci AR, Nakamura K, Kizuki M, Takano T. Family structure and health, how companionship acts as a buffer against ill health. Health Qual Life Out 2007; 5:61.

7. Roelfs DJ, Shor E, Kalish R, Yogev T. The rising relative risk of mortality for singles: meta-analysis and meta-regression. Am J Epidemiol 2011; 174:379-89.

8. Wood RG, Goesling B, Avellar S. The effects of marriage on health: a synthesis of recent research evidence. Princeton: Mathematica Policy Research Inc.; 2007.

9. Koball HL, Moiduddin E, Henderson J, Goesling $\mathrm{B}$, Besculides M. What do we know about the link between marriage and health? J Fam Issues 2010; 31:1019-40.

10. Barrett AE, Turner RJ. Family structure and mental health: the mediating effects of socioeconomic status, family process, and social stress. J Health Soc Behav 2005; 46:156-69.

11. Feijen-de Jong EI, Jansen DE, Baarveld F, van der Schans CP, Schellevis FG, Reijneveld SA. Determinants of late and/or inadequate use of prenatal healthcare in high-income countries: a systematic review. Eur J Public Health 2012; 22:904-13.

12. Raatikainen K, Heiskanen N, Heinonen S. Marriage still protects pregnancy. BJOG 2005; 112:1411-6.

13. Kiernan K, Pickett KE. Marital status disparities in maternal smoking during pregnancy, breastfeeding and maternal depression. Soc Sci Med 2006; 63:335-46

14. Shah PS, Zao J, Ali S. Maternal marital status and birth outcomes: a systematic review and metaanalyses. Matern Child Health J 2011; 15:1097-109.

15. Zeitlin JA, Saurel-Cubizolles MJ, Ancel PY; EUROPOP Group. Marital status, cohabitation, and the risk of preterm birth in Europe: where births outside marriage are common and uncommon. Paediatr Perinat Epidemiol 2002; 16:124-30.
16. Luo ZC, Wilkins R, Kramer MS; Fetal and Infant Health Study Group of the Canadian Perinatal Surveillance System. Disparities in pregnancy outcomes according to marital and cohabitation status. Obstet Gynecol 2004; 103:1300-7.

17. Alves E, Correia S, Barros H, Azevedo A. Prevalence of self-reported cardiovascular risk factors in Portuguese women: a survey after delivery. Int J Public Health 2012; 57:837-47.

18. Larsen PS, Kamper-Jørgensen M, Adamson A, Barros H, Bonde JP, Brescianini S, et al. Pregnancy and birth cohort resources in Europe: a large opportunity for aetiological child health research. Paediatr Perinat Epidemiol 2013; 27:393-414.

19. Kotelchuck M. An evaluation of the Kessner Adequacy of Prenatal-care Index and a proposed adequacy of prenatal-care utilization index. Am J Public Health 1994; 84:1414-20.

20. Heaman MI, Green CG, Newburn-Cook CV, Elliott LJ, Helewa ME. Social inequalities in use of prenatal care in Manitoba. J Obstet Gynaecol Can 2007; 29:806-16.

21. McKeever M, Wolfinger NH. Thanks for nothing: income and labor force participation for nevermarried mothers since 1982. Soc Sci Res 2011; 40:63-76.

22. Lawlor DA, Mortensen L, Andersen AM. Mechanisms underlying the associations of maternal age with adverse perinatal outcomes: a sibling study of 264695 Danish women and their firstborn offspring. Int J Epidemiol 2011; 40:1205-14.

23. Instituto Nacional de Estatística. Estatísticas demográficas 2011. Lisboa: Instituto Nacional de Estatística; 2013.

24. Erfani A, Beaujot R. Attitude toward childbearing outside of marriage in Canada. J Comp Fam Stud 2009; 40:759-73.

25. Ferreira P, Aboim S. Modernidade, laços conjugais e fecundidade: a evolução recente dos nascimentos fora do casamento. Análise Social 2002; XXXVII:411-6.

26. Neto MT. Perinatal care in Portugal: effects of 15 years of a regionalized system. Acta Paediatr 2006; 95:1349-52.

27. Alves E, Lunet N, Correia S, Morais V, Azevedo A, Barros H. Medical record review to recover missing data in a Portuguese birth cohort: agreement with self-reported data collected by questionnaire and inter-rater variability. Gaceta Sanit 2011; 25:211-9.

28. Jadva V, Badger S, Morrissette M, Golombok S. "Mom by choice, single by life's circumstance..." Findings from a large scale survey of the experiences of single mothers by choice. Hum Fertil (Camb) 2009; 12:175-84.

Submitted on 01/Apr/2014

Final version resubmitted on 16/Dec/2014

Approved on 09/Jan/2015 